\title{
Analysis of the clinical response and changes in the expression of TNF- $a$ and its TNFR1 and TNFR2 receptors in patients with psoriasis vulgaris treated with ustekinumab
}

\author{
Dominika Ligia Wcisło-Dziadecka ${ }^{1, A-F}$, Beniamin Grabarek ${ }^{2,3,4, C, D}$, Celina Kruszniewska-Rajs ${ }^{2, C}$, \\ Joanna Magdalena Gola ${ }^{2, B, C, E}$, Klaudia Simka ${ }^{5, C}$, Urszula Mazurek ${ }^{6, D-F}$ \\ ${ }^{1}$ Department of Cosmetology, School of Pharmaceutical Sciences in Sosnowiec, Medical University of Silesia in Katowice, Poland \\ 2 Department of Molecular Biology, School of Pharmaceutical Sciences in Sosnowiec, Medical University of Silesia in Katowice, Poland \\ ${ }^{3}$ Maria Sklodowska-Curie National Research Institute of Oncology Krakow Branch, Poland \\ ${ }^{4}$ Department of Histology, Cytophysiology and Embryology in Zabrze, Silesian University of Technology, Faculty of Medicine, Katowice, Poland \\ ${ }^{5}$ Department of Internal Medicine, School of Health Sciences in Bytom, Medical University of Silesia in Katowice, Poland \\ ${ }^{6}$ Józef Tyszkiewicz Higher School in Bielsko-Biała, Poland
}

A - research concept and design; B - collection and/or assembly of data; $C$ - data analysis and interpretation;

$\mathrm{D}$ - writing the article; $\mathrm{E}$ - critical revision of the article; $\mathrm{F}$ - final approval of the article

\section{Address for correspondence \\ Dominika Wcisło-Dziadecka}

E-mail: ddziadecka@interia.pl

\section{Funding sources}

This research was financed by Medical University of Silesia in Katowice, Poland, on the basis of decision No. KNW-1-029/N/6/0. This research was supported in part by PLGrid Infrastructure.

Conflict of interest

None declared

Received on April 28, 2018

Reviewed on January 14, 2019

Accepted on September 25, 2019

Published online on March 3, 2020

Cite as

Wcisło-Dziadecka DL, Grabarek B, Kruszniewska-Rajs C, Gola JM, Simka K, Mazurek U. Analysis of the clinical response and changes in the expression of TNF- $a$ and its TNFR1 and TNFR2 receptors in patients with psoriasis vulgaris treated with ustekinumab. Adv Clin Exp Med. 2020;29(2):235-241. doi:10.17219/acem/112607

DOI

10.17219/acem/112607

\section{Copyright}

Copyright by Author(s)

This is an article distributed under the terms of the

Creative Commons Attribution 3.0 Unported (CC BY 3.0)

(https://creativecommons.org/licenses/by/3.0/)

\section{Abstract}

Background. Ustekinumab is a monoclonal antibody that shows the ability to bind to subunit p40, common for interleukin 12 (IL-12) and IL-23, which prevents the activation of the JAK STAT signaling pathway.

Objectives. The objective of the study was to evaluate the efficacy of therapy that uses anti-IL-12/23 medicine in patients with psoriasis vulgaris, based on the disease clinical progression indices (Psoriasis Area and Severity Index (PASI), Dermatology Life Quality Index (DLQI) and Body Surface Area (BSA)) and to determine the possibilities of using changes in the expression profiles of tumor necrosis factor a (TNF-a), tumor necrosis factor receptor (TNFR1) and TNFR2 as molecular markers showing the response to ustekinumab therapy.

Material and methods. The group under study was composed of 14 patients (10 men and 4 women, aged $49.3 \pm 10.2$ years) with diagnosed psoriasis vulgaris, treated with ustekinumab. The group was divided into subgroups because of the selected 3 stages of therapy. The control group consisted of 20 healthy volunteers (11 men and 9 women, aged $46 \pm 10$ years). The 120 -week long observation involved a clinical assessment of the patients (PASI, BSA and DLQI), based on the following scheme: $0-4-12$ weeks of the observation. The analysis of molecular changes in the TNF- $a$, TNFR1 and TNFR2 expression profiles was performed with the quantitative reverse-transcription polymerase chain reaction (RT-qPCR) method, using the patients' full blood. The statistical analysis was performed with STATISTICA v. 12.0 PL (StatSoft, Inc., Tulsa, USA) with the level of statistical significance $p<0.05$.

Results. Gradually reduced PASI, BSA and DLQI values were observed during anti-IL-12/23 therapy. An increased level of the TNF-a transcription activity was observed in the analyzed group when compared to the control. Correlations between the clinical and molecular parameters were also indicated.

Conclusions. Ustekinumab constitutes an efficient and safe form of pharmacotherapy in psoriasis vulgaris. We did not observe any reduced efficacy of the treatment when reclassifying patients for the therapy. Tumor necrosis factor a, TNFR1 and TNFR2 may serve as supplementary markers of molecular response to the medicine.

Key words: psoriasis, TNF-a, molecular marker, anti-IL-12/23 therapy, JAK STAT signaling pathway 


\section{Introduction}

Psoriasis is a multi-factor pro-inflammatory disease, the most characteristic phenomenon of which is parakeratosis. ${ }^{1-3}$ Moreover, the disease involves the increased risk of concurrent metabolic syndrome, arterial hypertension, cardiovascular diseases, and ischemic brain stroke. ${ }^{2,4-6}$ Development of molecular biology made it possible to observe and confirm the changes occurring in the expression of cytokines, e.g., transforming growth factor $\beta$ (TGF- $\beta$ ), tumor necrosis factor $\alpha$ (TNF- $\alpha$ ) and interleukins (IL-12, IL-23 and IL-17) in the said disease. ${ }^{2,7}$

Biological anti-cytokine therapy is intended for those patients for whom conventional therapies proved to be insufficiently effective or in cases where contraindications for their application occurred. Moreover, in this group of patients, psoriasis has got a severe course and a high degree of lesion advancement (Psoriasis Area and Severity Index (PASI) $>10$ or Body Surface Area (BSA) $>10) .{ }^{7-9}$

Two big groups of anti-cytokine medicines are distinguished: TNF- $\alpha$ inhibitors (adalimumab, etanercept) and IL-12/23 inhibitor (ustekinumab), ${ }^{10,11}$ which owe their high efficacy to their unique activity: their focus on molecular objectives. $^{10-12}$

When binding to the mentioned subunit p40, ustekinumab prevents IL-12/23 from interacting with the receptor and activation of the JAK STAT signaling pathway and is also a monoclonal antibody oriented against the $\mathrm{p} 40$ subunit, common for IL-12 and IL-23. . $^{1,8}$

Therapy based on this medicine is comparably efficient in anti-TNF therapy and enables us to achieve remission of disease symptoms. ${ }^{1,8,13}$

Interaction between IL-12 and IL-23 and receptors on the cell surface activates the JAK STAT signaling pathway, ${ }^{14,15}$ the final products being the following: TNF- $\alpha$ and interferon gamma (IFN $\gamma),{ }^{16}$ which enhance IL-12/23 secretion, ${ }^{17}$ thereby causing intensified inflammation. ${ }^{18-20}$

Tumor necrosis factor $\alpha$ is mainly generated by the following: macrophages, monocytes, $\mathrm{T}$ and $\mathrm{B}$ lymphocytes, and its interactions with receptors TNFR1 and TNFR2 trigger activation of apoptosis or the NFKB pathway. ${ }^{21}$

To clinically assess the changes in patient, advancement of disease and efficacy of therapy in psoriasis vulgaris, the following scales are used: PASI, Dermatology Life Quality Index (DLQI) and BSA. ${ }^{22}$

\section{Objectives}

The objective of the study was to evaluate the efficacy of anti-IL-12/23 therapy in patients with psoriasis vulgaris, based on the clinical parameters (PASI, DLQI and BSA), and to analyze the transcription activity profiles of TNF- $\alpha$, TNFR1 and TNFR2. The possibility of using the changes in the expression of the analyzed genes as supplementary molecular markers of therapy efficacy was also determined.

\section{Material and methods}

Material used for the studies involved blood taken from 14 patients with psoriasis, classified for ustekinumab therapy. The blood was sampled before the administration of an ustekinumab dose and $2 \mathrm{~h}$ after its administration (one stage of the therapy lasted 40 weeks). The analyzed group was divided into 3 subgroups, as the patients had to be reclassified to a given pharmacotherapy program and a new stage of therapy had to be initiated: subgroup I included 14 patients (10 men and 4 women, aged $49.3 \pm 10.2$ years), subgroup II included 9 patients (7 men and 2 women, aged $50.1 \pm 7.64$ years) and subgroup III included 5 patients ( 3 men and 2 women, aged $52.8 \pm 7.98$ years). The interval between the subsequent inclusions to therapy was $4-6$ months. The need to reclassify the patients to anti-cytokine therapy resulted from the criteria of IL-12/23 therapy inclusion and from whether any of the patients show remission. This is due to the fact that, in accordance with the Polish guidelines for anti-IL-12/23 therapy, when patients undergo remission after 40 weeks of therapy, the treatment is terminated. When skin lesions reappear, patients are re-qualified for ustekinumab treatment (subgroup II and III). The number of patients suffering from psoriasis in I-III subgroups was associated with lasting remission, non-compliance of patients with recommendations and acute exacerbations, which resulted in the discontinuation of ustekinumab therapy (Fig. 1).

Patients classified for the study received ustekinum$\mathrm{ab}$ in the doses dependent on their body weight (45 mg or $90 \mathrm{mg}$ ) according to the following scheme: 0-412 weeks. The control group consisted of 20 healthy volunteers (11 women and 9 men, aged $46 \pm 10$ years) who gave their voluntary informed consent for the study.

Patients from the analyzed group were clinically examined on the day of therapy initiation, 4 weeks after they received the $1^{\text {st }}$ medicine dose, and then every 12 weeks thereafter. The molecular analysis was performed parallelly to the clinical analysis.

The molecular analysis involved, first of all, an extraction of total RNA with the use of Fenozol (A\&A

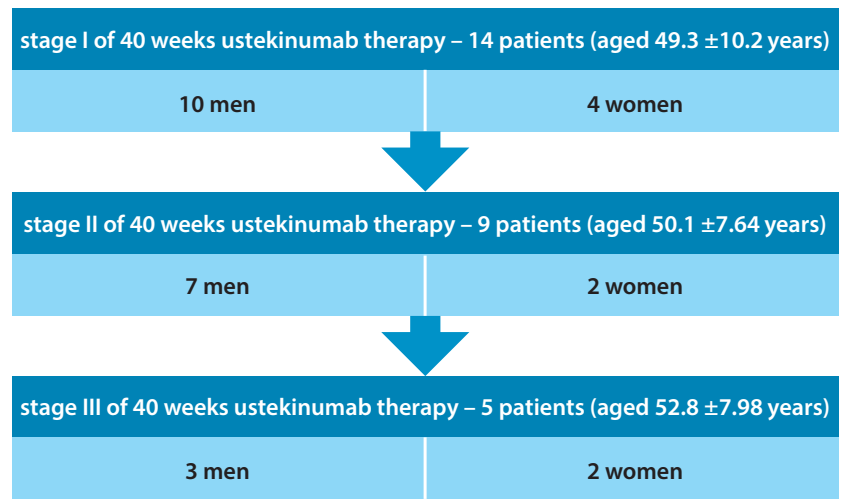

Fig. 1. Diagram showing which patients were involved in the subsequent phases of the study 
Biotechnology, Gdańsk, Poland), according to the producer's recommendation. The next stage was connected with the amplification of genes (TNF- $\alpha, T N F R 1$ and TNFR2) in the presence of $\beta$-actin, as an endogenic control, based on the quantitative reverse-transcription PCR reaction (RT-qPCR). The reaction was conducted with the use of a pair of starters, specific for the sequences of each analyzed gene and the use of SYBR Green Quantitect RT-PCR Reagent Kit (Qiagen, Valencia, USA), according to producer's recommendation.

The clinical analysis of the response to treatment was performed with the use of the following scales: PASI, DLQI and BSA. The statistical analysis was performed with the licensed version of STATISTICA v. 12.0 PL (StatSoft,
Inc., Tulsa, USA) and included the Shapiro-Wilk test, the Mann-Whitney U test, the Friedman's analysis of variance (ANOVA), and the Spearman correlation. The statistical analysis was performed assuming the statistical gravity factor $\mathrm{p}<0.05$.

\section{Results}

The changes in the transcription activity of the genes analyzed during one stage of therapy using ustekinum$\mathrm{ab}$ and in the control group were presented in the form of the quantity of mRNA copies of a given gene, converted into $1 \mu \mathrm{g}$ of total RNA (Table 1$)$.

Table 1. TNF-a, TNFR1 and TNFR2 expression profiles in patients with psoriasis vulgaris treated with ustekinumab and the control group (number of mRNA copies per $1 \mu \mathrm{g}$ RNA)

\begin{tabular}{|c|c|c|c|c|c|c|c|c|c|c|c|}
\hline \multirow{2}{*}{$\begin{array}{l}\text { Stage of } \\
\text { therapy }\end{array}$} & \multirow{2}{*}{$\begin{array}{c}\text { Time } \\
\text { [weeks } \\
\text { of therapy] }\end{array}$} & \multirow{2}{*}{$\begin{array}{c}\text { Before/ } \\
\text { after }\end{array}$} & \multicolumn{3}{|c|}{$T N F-a$} & \multicolumn{3}{|c|}{ TNFR1 } & \multicolumn{3}{|c|}{ TNFR2 } \\
\hline & & & median & $\begin{array}{c}\text { lower } \\
\text { quartile }\end{array}$ & $\begin{array}{c}\text { upper } \\
\text { quartile }\end{array}$ & median & $\begin{array}{c}\text { lower } \\
\text { quartile }\end{array}$ & $\begin{array}{c}\text { upper } \\
\text { quartile }\end{array}$ & median & $\begin{array}{c}\text { lower } \\
\text { quartile }\end{array}$ & $\begin{array}{c}\text { upper } \\
\text { quartile }\end{array}$ \\
\hline Control & - & - & 600000 & 300000 & 1000000 & 200000 & 60000 & 500000 & 300 & 40 & 1000 \\
\hline \multirow{10}{*}{1} & 0 & before & 3407975 & 499749 & 7662592 & 366589 & 59986 & 1986452 & 71 & 15 & 213 \\
\hline & 0 & after & 6027608 & 321856 & 49222471 & 2249138 & 815748 & 6864411 & 205 & 34 & 767 \\
\hline & 4 & before & 10908550 & 3161565 & 44516325 & 561627 & 155839 & 2184666 & 74 & 16 & 278 \\
\hline & 4 & after & 5733638 & 5292815 & 26745073 & 2117022 & 64335 & 3881999 & 318 & 59 & 1943 \\
\hline & 16 & before & 17453616 & 8902661 & 31385633 & 525608 & 55374 & 1626370 & 168 & 26 & 4545 \\
\hline & 16 & after & 25275607 & 14105295 & 35388972 & 1489566 & 118572 & 4818033 & 3334 & 74 & 8534 \\
\hline & 28 & before & 1889572 & 29263771 & 107209432 & 947764 & 6400335 & 17378728 & 193 & 918 & 11057 \\
\hline & 28 & after & 4293705 & 18846934 & 57529390 & 879275 & 7073464 & 45423569 & 285 & 782 & 16024 \\
\hline & 40 & before & 1157602 & 5085281 & 14371656 & 352167 & 1744295 & 5167842 & 49 & 847 & 11286 \\
\hline & 40 & after & 2500149 & 5564184 & 25853739 & 297111 & 362892 & 1735929 & 30 & 479 & 1653 \\
\hline \multirow{10}{*}{ ॥ } & 0 & before & 883689 & 128266 & 1279348 & 417425 & 171418 & 901541 & 19 & 11 & 94 \\
\hline & 0 & after & 1462641 & 892571 & 14678007 & 1539796 & 13251 & 9359111 & 814 & 107 & 152034 \\
\hline & 4 & before & 171418 & 40210 & 3242518 & 359281 & 274 & 709177 & 147 & 33 & 199 \\
\hline & 4 & after & 248168 & 33923 & 695135 & 475376 & 268837 & 475376 & 921 & 158 & 2480 \\
\hline & 16 & before & 223566 & 11406 & 1006370 & 286526 & 19572 & 1090188 & 106 & 66 & 7088 \\
\hline & 16 & after & 2056333 & 306159 & 4205319 & 219837 & 54823 & 1626370 & 100 & 30 & 927 \\
\hline & 28 & before & 10481 & 1144 & 108213 & 9699 & 3721 & 54996 & 134 & 1 & 1178 \\
\hline & 28 & after & 30533 & 621 & 50608 & 4826 & 3505 & 14792 & 5 & 1 & 21 \\
\hline & 40 & before & 14363 & 505 & 39021 & 24220 & 57 & 50104 & 237 & 125 & 968 \\
\hline & 40 & after & 256583 & 55930 & 1779532 & 978475 & 193273 & 1180987 & 116 & 13 & 252 \\
\hline \multirow{10}{*}{ III } & 0 & before & 143632 & 36749 & 307124 & 480153 & 26239 & 2094882 & 593 & 363 & 1444 \\
\hline & 0 & after & 453617 & 89488 & 530652 & 285461 & 214 & 648139 & 54 & 0 & 82 \\
\hline & 4 & before & 76257 & 43996 & 840591 & 1923 & 260 & 2571 & 3 & 0 & 5 \\
\hline & 4 & after & 52673 & 10320 & 134842 & 14071 & 50 & 36981 & 3 & 0 & 4 \\
\hline & 16 & before & 117354 & 47661 & 358023 & 4717 & 1383 & 103363 & 87 & 0 & 225 \\
\hline & 16 & after & 1496530 & 274268 & 3697534 & 2252 & 17 & 19421 & 179 & 39 & 3463 \\
\hline & 28 & before & 0 & 0 & 0 & 0 & 0 & 3 & 0 & 0 & 17 \\
\hline & 28 & after & 0 & 0 & 10 & 0 & 0 & 0 & 126 & 0 & 12482 \\
\hline & 40 & before & 0 & 0 & 0 & 0 & 0 & 0 & 596 & 8 & 1184 \\
\hline & 40 & after & 0 & 0 & 0 & 0 & 0 & 0 & 0 & 0 & 0 \\
\hline
\end{tabular}


As far as the molecular analysis is concerned, it may be observed that in the group under study, before therapy commencement, at stage I and II, the TNF- $\alpha$ expression was higher than that of the control group; however, it changed during stage III. TNFR1 expression remained always higher in the study group when compared with the control group, while TNFR2 is subject to overexpression when compared to the control, in the group of patients classified for stage III of therapy. A statistically significant difference in the TNF- $\alpha$ expression was observed between the group examined at stage I of therapy and the control group ( $\mathrm{p}=0.011593)$. We also ascertained the occurrence of a statistically significant transcription activity of TNFR 2 between the study group and the control group during the stage II of therapy $(\mathrm{p}=0.032511)$. The TNFR 1 expression in the study group is higher than that of the control group, whereas an increased number of TNFR 1 transcript copies was observed at the reclassification.

A higher quantity of TNFR1 receptor copies compared to those of TNFR2 is observed in the study group as opposed to the control group.

The analysis of changes in the expression profile of the analyzed genes before administration of another dose of ustekinumab and $2 \mathrm{~h}$ after its administration enabled us to note that the TNF- $\alpha$ expression basically increased after medicine administration. A similar tendency was observed in the case of TNFR 1 and TNFR 2 receptors expression. However, during stage III of the classification for the anti-IL-12/23 therapy, it was observed that receptor expression decreased after medicine administration when compared with the activity before administration of the next medicine dose.

The characteristics of the clinical parameters (PASI, DLQI and BSA) of therapy efficacy are presented in Table 2. A gradual decrease of all 3 values of clinical parameters of the response to treatment during its duration could be observed. We also did not observe any increase in the values of the analyzed parameters between the subsequent inclusions to the anti-IL-12/23 therapy.

We established that the differences in the values of the individual clinical indices during a given therapy stage are statistically insignificant (stage I: PASI $\mathrm{p}=0.00000$; DLQI $\mathrm{p}=0.00022$; BSA $\mathrm{p}=0.00028$; stage II: PASI $\mathrm{p}=0.02733$; DLQI $\mathrm{p}=0.04773$; BSA $\mathrm{p}=0.03875$, stage III: PASI $\mathrm{p}=0.04206$; DLQI $\mathrm{p}=0.05756$; BSA $\mathrm{p}=0.24066 \mathrm{NS})$.

We noted several statistically significant $(\mathrm{p}<0.05)$ correlations $(r)$ between the expression of the analyzed groups in a given moment of therapy and the clinical indices.

The correlation between DLQI and the expression of TNFR1 $(\mathrm{r}=0.660578)$ and TNFR2 $(\mathrm{r}=0.642229)$ may be observed during stage I in week 28 . A correlation between TNFR2 and DLQI $(\mathrm{r}=0.828571)$ and TNFR2 and BSA $(r=0.828571)$ is observed during stage II in the $4^{\text {th }}$ week of anti-cytokine therapy. At the moment stage III of therapy was commenced ( 0 weeks), a statistically significant correlation was observed between TNFR1 and DLQI $(\mathrm{r}=-0.900000)$ and TNFR1 and BSA $(\mathrm{r}=0.900000)$, TNFR 2 and BSA $(\mathrm{r}=0.900000)$. After 4 weeks of stage III of the therapy, statistically significant correlations occured between TNF- $\alpha$ expression and BSA (-0.900000), as well as TNFR1 expression and DLQI $(\mathrm{r}=-0.894427)$.

Table 2. Characteristics of the disease progress clinical parameters (PASI, DLQI and BSA) in patients with psoriasis vulgaris during the anti-IL-12/23 therapy (ustekinumab)

\begin{tabular}{|c|c|c|c|c|c|c|c|c|c|c|}
\hline \multirow{2}{*}{$\begin{array}{l}\text { Stage of } \\
\text { therapy }\end{array}$} & \multirow{2}{*}{$\begin{array}{c}\text { Time } \\
\text { [weeks } \\
\text { of therapy] }\end{array}$} & \multicolumn{3}{|c|}{ PASI } & \multicolumn{3}{|c|}{ DLQI } & \multicolumn{3}{|c|}{$\mathrm{BSA}$} \\
\hline & & median & $\begin{array}{c}\text { lower } \\
\text { quartile }\end{array}$ & $\begin{array}{c}\text { upper } \\
\text { quartile }\end{array}$ & median & $\begin{array}{c}\text { lower } \\
\text { quartile }\end{array}$ & $\begin{array}{c}\text { upper } \\
\text { quartile }\end{array}$ & median & $\begin{array}{c}\text { lower } \\
\text { quartile }\end{array}$ & $\begin{array}{c}\text { upper } \\
\text { quartile }\end{array}$ \\
\hline \multirow{4}{*}{ I } & 0 & 24 & 27 & 15 & 21 & 23 & 16 & 60 & 65 & 28 \\
\hline & 4 & 15 & 17 & 24 & 10 & 19 & 54 & 33 & 39 & 56 \\
\hline & 16 & 8 & 11 & 14 & 6 & 10 & 17 & 23 & 44 & 55 \\
\hline & 40 & 3 & 6 & 9 & 7 & 8 & 10 & 6 & 9 & 22 \\
\hline \multirow{4}{*}{$\|$} & 0 & 20 & 14 & 23 & 20 & 18 & 24 & 42 & 39 & 53 \\
\hline & 4 & 8 & 5 & 11 & 13 & 8 & 16 & 22 & 75 & 27 \\
\hline & 16 & 3 & 1 & 6 & 10 & 5 & 12 & 8 & 3 & 27 \\
\hline & 28 & 3 & 1 & 11 & 7 & 5 & 12 & 8 & 3 & 37 \\
\hline \multirow{5}{*}{ III } & 0 & 13 & 12 & 33 & 22 & 18 & 23 & 32 & 27 & 49 \\
\hline & 4 & 10 & 10 & 11 & 10 & 10 & 11 & 34 & 23 & 43 \\
\hline & 16 & 5 & 3 & 7 & 10 & 6 & 10 & 13 & 8 & 18 \\
\hline & 28 & 3 & 2 & 4 & 10 & 3 & 10 & 15 & 14 & 20 \\
\hline & 40 & 3 & 3 & 4 & 5 & 4 & 5 & 6 & 6 & 7 \\
\hline
\end{tabular}

PASI - Psoriasis Area and Severity Index; DLQI - Dermatology Life Quality Index; BSA - Body Surface Area. 


\section{Discussion}

In this study, we assessed the efficacy of pharmacotherapy with the use of ustekinumab in patients with psoriasis vulgaris. The analysis was performed either based on the clinical indices of the disease progress stage (PASI, DLQI and BSA) or on a molecular analysis of the changes in the transcription activity of genes encoding TNF- $\alpha$, TNFR1 and TNFR2. Fourteen patients with diagnosed psoriasis vulgaris were classified for the anti-IL-12/23 therapy. The said group was divided into 3 subgroups, as the patients needed to be reclassified to the biological treatment. This was caused by the occurrence and duration of the remission stage in some patients. The control group was composed of 20 healthy volunteers who gave their informed consent for the study. The whole period of the study within the framework of this work lasted 120 weeks, and the clinical and molecular analyses were performed during each stage of the treatment for 40 weeks.

The degrees of psoriasis advancement and the quality of life during ustekinumab therapy were assessed at the beginning of treatment, after 4 weeks and then every 12 weeks, which corresponded to the medicine administration schedule. The PASI, BSA and DLQI indices were used to assess the clinical condition of the patients. In order to efficiently assess the efficacy of the treatment, it is extremely necessary to use several scales of disease progress. ${ }^{23-25}$

Regarding the values of all 3 mentioned scales, a gradual decrease of their numerical values can be observed with the time of ustekinumab administration. This indicates that the applied anti-cytokine therapy is effective. Moreover, at the moment a given subsequent stage of anti-IL-12/23 treatment was commenced, lower values of PASI and BSA were observed when compared to the previous stages (PASI: $24>20>13$; BSA: $60>42>32$ ), and similarly in case of DLQI $(21>20<22)$. This would indicate that, despite the necessity to reclassify the patients for subsequent pharmacotherapy, their physical condition was better than before commencing the earlier stage of the anti-IL-12/23 medicine administration. This could suggest a long-term reduction of the inflammatory process. We were able to ascertain during our observation that there was a significant clinical improvement in the $40^{\text {th }}$ week of the treatment $(\mathrm{PASI}=3$; $\mathrm{BSA}=6$; DLQI: $7>6>5$ ), regardless of the therapy stage. Our observations show that the biggest difference between the values of PASI and BSA during stage I and II of the therapy was observed as soon as after 4 weeks, and the greatest decrease of the values of ratios was noted between 4 and 16 weeks after the treatment. Consequently, taking into account the whole period of the study, it may be stated that the efficacy of the anti-IL-12/23 therapy is actually not lower with regards to the specific stage of the therapy, ${ }^{1,8,13}$ and the period of clinical improvement seems to be extended.

The efficacy of the anti-IL-12/23 therapy was also ascertained with regards to patients with psoriatic arthritis, ${ }^{26,27}$ Crohn's disease ${ }^{28}$ and inflammatory bowel disease. ${ }^{29}$
It is extremely important to take into account the DLQI parameter to assess the efficacy of the applied pharmacotherapy, since it enables us to assume a holistic approach towards psoriatic patients. This makes it possible to observe the manner in which the treatment affects patients' self-esteem, performance of social roles, self-acceptance, and their reception by the social environment. ${ }^{22,30,31}$

The $2^{\text {nd }}$ part of the work involved the possibility of using TNF- $\alpha$, TNFR 1 and TNFR2 expression as supplementary molecular markers to diagnose psoriasis vulgaris and assess the efficacy of the anti-IL-12/23 therapy. To this end, on the basis of the RT-qPCR methods, we evaluated the number of mRNAs of the gene in $1 \mu \mathrm{g}$ of total RNA before administering the next dose of the medicine and $2 \mathrm{~h}$ after its administration. Personalization of medicine and molecular biological tools make it possible to increase both the number and safety of personalized therapeutic strategies. $^{10,32-34}$

It may be observed that in the group under study, before the initiation of therapy, at stage I and II, the TNF- $\alpha$ expression was higher than in the control group; however, it changed during stage III. The transcription activity of TNF- $\alpha$ during the first 2 stages of the treatment is compliant with the observations made by other researchers. ${ }^{35}$ The TNFR 1 expression remained always higher in the study group when compared with the control group, while TNFR2 is subject to overexpression when compared to the control, in the group of patients classified for stage III of therapy. The statistical analysis of these 2 groups showed 2 statistically important differences - for the TNF- $\alpha(\mathrm{p}=0.011593)$ and TNFR2 ( $\mathrm{p}=0.032511)$ transcription profiles. We noted the changes in the expression profiles of the analyzed genes during our observations; however, they proved to be statistically insignificant $(\mathrm{p}>0.05)$.

Moreover, changes in gene expressions are observed as early as after $2 \mathrm{~h}$ following medicine administration, which suggests its quick action and the possibility to observe the molecular changes. ${ }^{36,37}$

Olczyk-Kwiecień et al. indicated the possibility and usefulness of using changes in the TNF- $\alpha$ expression as a supplementary molecular marker in patients with rheumatoid arthritis (RA). ${ }^{37}$ Additionally, Komatsu et al. on the basis of their own observations emphasized the possibility to use TNF- $\alpha$ to determine the degree of lesion advancement in inflammatory bowel diseases, ${ }^{38}$ cardiovascular diseases and cancers. ${ }^{39,40}$

Our studies also suggest that it is possible to use the analysis of the expression profiles of the examined transcripts as supplementary molecular markers of the efficacy of psoriasis therapy. Reasons for this include the occurrence of statistically significant correlations between expression of the analyzed genes and the clinical indices of disease advancement. The possibility to combine the clinical and molecular parameters in diagnosing and assessing psoriasis is also confirmed by observations made by other 
research groups. They also observed higher levels of cytokine, which was analyzed by us in the group of psoriatic patients compared with healthy persons. ${ }^{35}$

The molecular mechanism of ustekinumab section is connected with its binding of the $\mathrm{p} 40$ subunit, common for IL-12 and IL-23, thus preventing the interleukins from interacting with the receptors. Consequently, the signaling pathways activated by IL-12 and IL-23 are suppressed. Tumor necrosis factor $\alpha$ constitutes the main, final product of the JAK STAT signaling pathway, which is activated by IL-12 and IL-23. Consequently, we should expect lower expression of the analyzed gene under the influence of antiIL-12/23 therapy. We observed the complete suppression of the gene in the group of patients at the end of stage III of the treatment. The observed expression of the analyzed cytokine and its receptors, even during the anti-IL-12/23 therapy, may result from the mechanism of ustekinum$\mathrm{ab}$ action. Ustekinumab hinders the bioactivity of IL-12 and IL-23, preventing the $\mathrm{p} 40$ subunit from binding with IL-12R $\beta 1$ receptor, which is found at the surface of the immune system cells. For that reason, ustekinumab is not able to bind with IL-12/23 which have already interacted with IL-12R $\beta 1.13$ The continuous expression of TNF- $\alpha$ may indicate the presence of a certain pool of IL-12/23 that is not naturalized by ustekinumab. At the same time, the signaling pathways leading to TNF- $\alpha$ secretion are activated. Such observations are supported by the values of clinical parameters during pharmacotherapy, indicating an improvement. It must be noted that TNF- $\alpha$ shows activity that intensifies IL-12/23 secretion, ${ }^{17}$ leading to permanent inflammation. ${ }^{18-20}$

\section{Conclusions}

The obtained results of the clinical and molecular analyses in patients with psoriasis vulgaris during the antiIL-12/23 therapy indicate the efficacy of ustekinumab. It also seems that TNF- $\alpha$ could serve as a supplementary molecular marker in the diagnostics of psoriasis and the evaluation of the efficacy and safety of anti-cytokine therapy. In light of our observations, anti-cytokine therapy, oriented on molecular objectives, may constitute an effective form of therapy in cases of psoriasis vulgaris.

When evaluating the pharmacotherapy results, one should take into account the scale of disease clinical progression and the changes in the expression profiles of the analyzed genes.

\section{ORCID iDs}

Dominika Ligia Wcisło-Dziadecka

(D) https://orcid.org/0000-0003-0501-7592

Beniamin Grabarek (D) https://orcid.org/0000-0003-1633-7145 Celina Kruszniewska-Rajs (D) https://orcid.org/0000-0002-2504-6289 Joanna Magdalena Gola (D) https://orcid.org/0000-0002-3089-0409 Klaudia Simka (D) https://orcid.org/0000-0003-3900-0473 Urszula Mazurek (D) https://orcid.org/0000-0003-1181-4934

\section{References}

1. Tsoi LC, Stuart PE, Tian C, et al. Large scale meta-analysis characterizes genetic architecture for common psoriasis associated variants. Nat Commun. 2017;24(8):1-8.

2. Baran A, Kiluk P, Myśliwiec H, Flisiak I. Znaczenie lipidów w łuszczycy. Przegl Dermatol. 2017;104:619-635.

3. Albareda M, Ravella A, Castelló M, Saborit S, Paramiguel L, Vila L. Metabolic syndrome and its components in patients with psoriasis. Springerplus. 2014;3:612.

4. Lønnberg AS, Skov L, Skytthe, Kyvik KO, Pedersen OB, Thomsen SF. Association of psoriasis with the risk for type 2 diabetes mellitus and obesity. JAMA Dermatol. 2016;152(7):761-767.

5. Guo P, Luo Y, Mai G, et al. Gene expression profile based classification models of psoriasis. Genomics. 2014;103(1):48-55.

6. Michalak-Stoma A, Bartosińska J, Kowal M, Juszkiewicz-Borowiec M, Gerkowicz A, Chodorowska G. Serum levels of selected Th17 and Th22 cytokines in psoriatic patients. Dis Markers. 2013;35(6):625-631.

7. Szepietowski J, Adamski Z, Chodorowska G, et al. Rekomendacje Polskiego Towarzystwa Dermatologicznego dotyczące stosowania leków biologicznych w łuszczycy zwyczajnej i stawowej (łuszczycowym zapaleniu stawów). Przegl Dermatol. 2010;97:1-13.

8. Jaśkiewicz-Nyckowska D, Szczerkowska-Dobosz A, Czubek M,Purzyńska-Bohdan D. Problemy dotyczące fałszywie dodatnich testów laboratoryjnych podczas kwalifikacji do programu "Leczenia ciężkiej postaci łuszczycy plackowatej" na podstawie dwóch przypadków. Przegl Dermatol. 2015;102:33-36.

9. Wcisło-Dziadecka D, Zbiciak M, Wcisło-Brzezińska L, Mazurek U. Anticytokine therapy for psoriasis - not only TNF blockers: Overview of reports on the effectiveness of therapy with IL-12/IL-23 and T and B lymphocyte inhibitors. Post Hig Med Dosw (Online). 2016;70:1198-1205.

10. Wcisło-Dziadecka, Zbiciak-Nylec M, Brzezińska-Wcisło L, Bębenek AK, Kaźmierczak A. Newer treatments of psoriasis regarding IL-23 inhibitors, phosphodiesterase 4 inhibitors, and Janus kinase inhibitors. Dermatol Ther. 2017;30(6):1-8.

11. Kwiek B, Narbutt J, Sysa-Jędrzejowksa A, Lagner A, Lesiak A. Long-term treatment of chronic plaque psoriasis with biological drugs can control platelet activation: Targeting the bridge between inflammation and atherothrombosis. Postepy Dermatol Alergol. 2017;34(2):131-137.

12. Salomon J, Szepietowski J. Ustekinumab - nowy lek biologiczny w leczeniu łuszczycy. Przegl Dermatol. 2010;97:61-67.

13. Watford WT, Hissong BD, Bream JH, Kanno Y, Mull J, O'Shea JJ. Signaling by IL-12 and IL-23 and the immunoregulatory roles of STAT4. Immunol Rev. 2004;202:139-156.

14. Teng MW, Bowman EP, McElwee JJ, et al. IL-12 and IL-23 cytokines: From discovery to targeted therapies for immune-mediated inflammatory diseases. Nat Med. 2015;21(7):719-729.

15. Cyman M, Kotulak A, Ślebioda T, Kmieć Z. Cell-mediated innate and adaptive immune mechanisms in the pathogenesis of inflammatory bowel disease. Forum Med Rodz. 2016;10(3):238-247.

16. Watford WT, Moriguci M, Morinobu, O'Shea JJ. The biology of IL-12: Coordinating and adaptive immune responses. Cytokine Growth Factor Rev. 2003;14(5):361-368.

17. Horssen J, Schaik P, Witte M. Inflammation and mitochondrial dysfunction: A vicious circle in neurodegenerative disorders? Neurosci Lett. 2017;710:132931. doi:10.1016/j.neulet.2017.06.050

18. Cacquevel M, Lebeurrier N, Cheenne S, Vivien D. Cytokines in neuroinflammation and Alzheimer's disease. Curr Drug Targets. 2004;5(6): 529-534.

19. Netea MG, Balkwill F, Dinarello CA, et al. A guiding map for inflammation. Nat Immun. 2017;18(8):826-831.

20. Eder P, Łykowska-Szuber P, Stawczyk-Eder K, et al. Mechanizmy działania inhibitorów czynnika martwicy nowotworów a. Przegl Gastroenterol. 2011;6(5):290-298. doi:10.5114/pg.2011.25377

21. Bożek A, Reich A. How to reliably evaluate the severity of psoriasis? [in Polish]. Forum Dermatologicum. 2016;2(1):6-11.

22. Spuls PI, Lecluse LL, Poulsen ML, Bos JD, Stern RS, Nijsten T. How good are clinical severity and outcome measures for psoriasis? Quantitative evaluation in a systematic review. J Invest Dermatol. 2010;130(4): 933-943.

23. Puzenat E, Bronsard V, Prey S, et al. What are the best outcome measures for assessing plaque psoriasis severity? A systematic review of the literature. J Eur Acad Dermatol Venereol. 2010;24(Suppl 2):10-16. 
24. Adil M, Kumar-Singh P, Maheswari K. Clinical evaluation of omega-3 fatty acids in psoriasis. Dermatol Rev. 2017;104:314-323.

25. Chimenti MS, Ortolan A, Lorenzin M, et al. Effectiveness and safety of ustekinumab in naïve or TNF-inhibitors failure psoriatic arthritis patients: A 24-month prospective multicentric study. Clin Rheumatol. 2018;37(2):397-405.

26. Roberts J, O'Reilly DD, Rahman P. A review of ustekinumab in the treatment of psoriatic arthritis. Immunotherapy. 2018;10(5):361-372.

27. Wils $P$, Bouhnik $Y$, Michetti $P$, et al; Groupe d'Etude Thérapeutique des Affections Inflammatoires du Tube Digestif (GETAID). Long-term efficacy and safety of ustekinumab in 122 refractory Crohn's disease patients: A multicentre experience. Aliment Pharmacol Ther. 2018;47(5):588-595.

28. Barré A, Colombel JF, Ungaro R. Review article: Predictors of response to vedolizumab and ustekinumab in inflammatory bowel disease. Aliment Pharmacol Ther. 2018;47(7):896-905. doi:10.1111/apt.14550

29. Molina-Leyva A, Almodovar-Real A, Carlos-Ruiz C, Molina-Leyva I, Naranjo-Sintes B, Jimenez-Moleon JJ. Distribution pattern of psoriasis, anxiety and depression as possible causes of sexual dysfunction in patients with moderate to severe psoriasis. An Bras Dermatol. 2015;90(3):338-345.

30. Petit V, Makara-Studzińska M, Pietrzak A, Chodorowska G. Stigmatization in psoriasis patients. Pol Merk Lek. 2014;37(221):301-304.

31. Spuls PI, Lecluse LL, Poulsen ML, Bos JD, Stern RS, Nijsten T. How good are clinical severity and outcome measures for psoriasis? Quantitative evaluation in a systematic review. J Invest Dermatol. 2010;130(4): 933-943.

32. Bosman FT, Yan P. Patologia molekularna raka jelita grubego. Pol J Pathol. 2014;65(4):1-11.
33. Shveta, Agarwal K, Chander R, Agarwal S. Serum levels of se-selectin, TNF- $\alpha$ and IL-1 $\beta$ in patients of psoriasis before and after topical therapy in patients of psoriasis. Int J Curr Res. 2017;9(8):55837-55840.

34. Solberg SM, Sandvik LF, Eidsheim M, Jonsson R, Bryceson YT, Appel S. Serum cytokine measurements and biological therapy of psoriasis: Prospects for personalized treatment? Scand J Immunol. 2018; 88(6):e12725.

35. Wcisło-Dziadecka D, Grabarek B, Zmarzły N, et al. Influence of adalimumab on the expression profile of genes associated with histaminergic system in the skin fibroblasts in vitro. Biomed Res Int. 2018;2018: 1582173. doi:10.1155/2018/1582173

36. Wcisło-Dziadecka, Gola J, Grabarek B, Mazurek U, Brzezińska-Wcisło L Kucharz EJ. Effect of adalimumab on the expression of genes encoding TNF-a signal paths in skin fibroblasts in vitro. Postep Dermatol Alergol. 2018;35(4):413-422.

37. Olczyk-Kwiecień B, Wisłowska M, Stępień K. The critical study about the correlation of tumor necrosis factor alpha, C-reactive protein and seromucoid level in serum with parameters of disease activity in seropositive and seronegative rheumatoid arthritis patients. Reumatologia. 2006;44(4):205-212.

38. Komatsu M, Kobayashi D, Saito K, et al. Tumor necrosis factor alpha in serum of patients with inflammatory bowel disease as measured by highly sensitive immuno-PCR. Clin Chem. 2001;47(7):1297-1301.

39. Grabarek B, Bednarczyk M, Mazurek U. The characterization of tumor necrosis factor alpha (TNF- $a$ ), its role in cancerogenesis and cardiovascular system diseases and possibilities of using this cytokine as a molecular marker. Acta Univ Lodz Folia Biol Oecol. 2017;13(1):1-8.

40. Serefican H, Goksugur N, Bugdayci G, Polat M, Parlak AH. Serum visfatin, adiponectin, and tumor necrosis factor alpha (TNF-a) levels in patients with psoriasis and their correlation with disease severity. Acta Dermatovenerol Croat. 2016;24(1):13-19. 